\title{
Financial Stability of Islamic and Conventional Banks of the MENA Region: Post and Pre-Crisis of CAMELS Framework
}

\author{
Joudar Fadoua \\ $\mathrm{PhD}$ Researcher \\ Faculty of Law, Economics, and Social Sciences \\ Hassan First University, Settat, Morocco \\ E-mail: joudarfadoua@gmail.com \\ Dinar Brahim $P h D$ \\ Professor \\ Faculty of Law, Economics, and Social Sciences \\ Hassan First University, Settat, Morocco \\ E-mail: bh.dinar@gmail.com
}

Received: August 13, 2020

doi: I0.4628I/ijibfr.v4i2.784
Accepted: August 30, 2020

Online Published: September 27, 2020

\begin{abstract}
The present study provides new empirical evidence of bank stability measure for 12 Islamic and conventional banks in the MENA region, for a period from 2005 to 20I4. The most known method of measuring bank stability is using CAMELS variables; it was adopted by multiple central banks. After calculating financial ratios for the CAMELS framework, we calculate the average for each variable for the two types of banks, for three periods: Pre-crisis 2005-2006, Subprime Crisis 2007-2008, and Post-Crisis 2009-20I4, to examine the effect of the crisis on the soundness of Islamic and conventional banks.
\end{abstract}

Keywords: Banks Stability, CAMELS, Conventional Banks, Financial Stability, Islamic Banks.

\section{Introduction}

Islamic finance has shown spectacular development in recent years. Some theorists explain this growth by the ambition of financiers to find an alternative to conventional finance, which has shown great instability, the last was the subprime crisis, which laid bare the entire conventional financial system.

Thus, we examine through this article the effect of the subprime crisis on the two financial systems based on a sample of 6 Islamic banks and 6 conventional banks in the MENA region, for the period from 2005 to 20I4. Our study is based on the CAMEL method as a tool for measuring banking stability.

Many economies suffer from the fragility of their financial systems due to macroeconomic changes. Also, the banking sector's concentration on short-term lending has long been seen as one of the main causes of recent crises.

Indeed, the conventional financial system has been the subject of several studies, including one by Minsky (I986), who recognized the unstable nature of conventional finance.

Thus, Fisher (1936) and Simons (1948) recommended in their work, banking systems similar to Islamic banking systems, with the same characteristics (Askari \& Krichene, 20I4).

Thus, based on the need for a more stable system, Islamic banking theory strongly defends the ability of the Islamic financial system to cope with potential shocks. The explanation of this stabilizing character is mainly based on the nature of this system.

Indeed, many researchers justify this resilience by profit and loss sharing (PLS) contracts, which are the main tool of Islamic financial intermediation, because investment deposits can absorb shocks on the liability side of the balance sheet (Salman, 2007; Bourkhis \& Nabi, 2013).

Similarly, Chishti (1985), financing through PLS contracts, offers more financial soundness because they do not operate through speculative transactions, which are at the origin of several episodes of instability.

On the other hand, the financial stability of Islamic banks has been largely explained by the quality of their assets. 
According to Sakti and Mohamad (2018), the quality of Islamic assets is due to the fact that Islamic banks have high levels of deposits and capital, Bourkhis and Nabi (2013) consider that PLS contracts do not oblige the investor to present guarantees to reduce credit risk, which improves the quality of these assets. Indeed, the quality of Islamic assets is explained by the prohibition of the sale and transfer of debt (Zainol \& Kassim, 2012).

From another perspective, the stability of the Islamic banking system is often explained by the link between the real economy and the financial sphere. Islamic finance operates only in the acquisition of tangible assets and prohibits the sale of claims (Chapra, 2009; Tayyebi, 2009).

\section{Literature Review}

\section{I Financial Stability and Physics: Which Relation?}

The concept of stability is borrowed from the physical sciences, and more specifically from the rules of movement and equilibrium. It is a stable equilibrium when the latter endures a disturbance that takes it away from its fundamental position but returns to it naturally and without any external intervention.

Thus, according to the laws of physics, stability is an inherent feature of the system and not a state that may or may not occur at a given time.

If the system returns to its equilibrium after being disturbed from its initial point, it becomes stable. In concrete terms, the system fluctuates around the equilibrium, gradually returning to equilibrium. If it moves away from this equilibrium, it is unstable. It could even be stable to certain disturbances, and not be stable to others according to their magnitude. Hence the non-linear nature of the system.

As a result, financial stability is considered in the same way, as a feature of the system.

Allen and Gale (2006) define financial stability as "the property of an economic system," and that a system is said to be stable when it does not deteriorate into instability following a disturbance.

The concept of financial stability is therefore not new. It has been explicitly discussed by several theories explaining economic and financial crises. However, it is the name that represents new need.

\subsection{Why Financial Stability is Important?}

The importance of financial stability lies in its objective of maintaining monetary stability through the central bank, and ensuring an environment conducive to the development of the economic activity. bankruptcies.

Indeed, financial instability is likely to impose high costs on the economy, as financial institutions are threatened by

Moreover, financial instability can be accompanied by a temporary recession in economic development, as the rationality of agents is limited.

Despite the positive effects of financial sector development in many countries, they also experienced periods of weakening economic development due to heavy spending resulting from bouts of financial instability.

For these reasons, greater emphasis has been placed on financial stability, and it has become a key objective of decisionmaking policies (Bank of Korea; Bank Negara Malaysia).

\subsection{What is Financial Stability?}

The concept of financial stability is complex. Thus, two different approaches have been adopted to define it. Some authors prefer to define financial stability while others try to define it by its absence, i.e. financial instability.

Schinasi (2004) considers that a financial system is stable when it can facilitate the performance of an economy on the one hand, and able to eliminate financial disturbances that may occur endogenously or that are caused by undesirable and unexpected events on the other hand.

This definition emphasizes the relationship between financial stability and economic performance and considers it as important.

Padoa-Schioppa (2003) assumes that financial stability is the condition by which a financial system can withstand shocks without giving way to disruptions in savings allocations.

Crockett (1997) considers that financial stability is inherent in the stability of the institutions that make up the financial system as a whole. This multidimensional aspect of financial stability stipulates the absence of stress that could cause measurable economic harm.

From a broader perspective, Patat (2000) suggests a multidimensional definition of financial stability, which refers not only to the proper functioning of the components of the financial system, but also to the strength of the linkages between them. The concept of instability preceded the one of stability, and it was only after periods of disequilibrium that the authorities began to worry about maintaining financial stability and develop prudential frameworks.

Other authors defined financial stability based on its opposite. Financial instability is defined by Mishkin (I997), 
which assumes that financial instability refers to the variousdevices that arise from shocks and that prevent the financial system from properly playing its role of channeling funds to investment opportunities.

Ferguson (2002) states that financial instability is a major fluctuation in the prices of financial assets, a distortion of the functioning of the market, and the available appropriations, which creates a significant gap between expenditure and economic production capacity.

According to Chant, Lai, Illing, and Fred (2003), financial instability is the setoff circumstances that produce or are likely to produce a decline in an economy's performance.

Moreover, bank stability is a key condition of financial stability, because bank failures and failures of long-term savings and borrowing instruments are responsible for the lack of confidence in financial intermediaries, which acts as a brake on economic growth (Foot, 2003).

In this perspective, we consider for the present paper the definition proposed by BCEAO (2006), that « financial stability refer to the bank ability of to withstand significant shocks and the resolution of macroeconomic imbalances, thereby reducing the probability of a break in the financial intermediation between savings and investment " (Mansour \& Zouari, 2018).

\subsection{Measure Banking Stability}

\subsection{CAMELS Method}

To measure bank stability, the CAMELS method we widely used. It represents a scoring method for financial institutions, which was the first applied in 1979 by the Federal Financial Institution Examination Council to evaluate financial institutions in the United States (Uyen, 20II; Faouzi \& Houhou, 2008; Balteş, Rodean, \& Daciana, 20I4).

2013).

It was subsequently adopted by many central banks because of its relevance to financial soundness (Roman \& Sargu,

Thus, the acronym CAMELS is developed from the initials of five indicators of banking soundness, namely:

C: Capital adequacy

A: Asset quality

M: Management quality

E: Earnings

L: Liquidity

The sixth "S" indicator was introduced in 1996; it refers to the sensitivity to market risk. For reasons of its unavailability in the annual bank reports, we will not use this indicator (Roman \& Şargu, 2013; Baltes et al., 20I4; Uyen, 20II).

Indeed, these indicators are part of the Financial Soundness Indicators (FSIs) established by the International Monetary Fund to examine the vulnerability of a financial system and assess its ability to cope with potential shocks. (IMF, 2006)

\section{Financial Stability of Commercial Banks and Islamic Bank:Literature Review}

\section{ICapital Adequacy}

Capital adequacy refers to the level of capital that can achieve certain equilibrium even in the presence of the risks faced by financial institutions. Its role is to absorb potential losses (Uyen, 20II)

To evaluate capital adequacy, there are several ratios known as the Capital Adequacy Ratio (CAR). We use the following ratio:

$$
\mathrm{CAR}=\frac{\text { Total Equity }}{\text { Total Assets }}(\mathrm{I})
$$

Indeed, this ratio is recognized as being more representative in times of crisis, because there is a close relationship between the level of equity and the probability of bank failure. As developed by Santomero and Watson (1977), the higher the ratio, the lower the probability of failure, as shown in the following chart: 


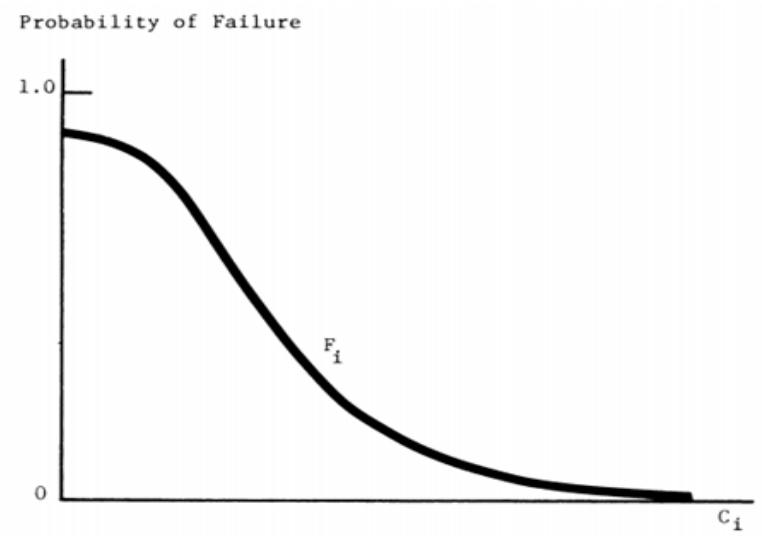

Figure I. Probability of Failure for an Individual Bank, Given Various Capital Quantities Source: Santomero and Watson (I977)

Thus, the higher this ratio, the more stable the bank, and the lower the risk of default.

Several studies have compared the capital adequacy of Islamic banks and conventional banks, to present evidence on the stability of these two types of banks.

The results of these studies are very diverse.

Some studies confirm that there is no significant difference between Islamic banks and conventional banks in terms of capital adequacy.

In particular, Bourkhis and Nabi (2013) find no difference between the two banks for the period before the crisis, during the crisis and after the crisis; therefore they conclude that even the crisis did not affect the capitalization of both types of banks.

Other studies confirm that the solvency of Islamic banks is higher than the solvency of conventional banks (Ouerghi, 20I4; Beck, Demirgüç-Kunt, \& Merrouche; Srairi, 2010).

In the same line, Wahid and $\operatorname{Dar}$ (2016) find that the ratio of equity to total assets of Islamic banks is higher, except for the post-crisis period when the capital adequacy ratio of conventional banks exceeds the one of Islamic banks.

Contrary to other research, which has concluded that conventional banks have a high level of capital, notably the study conducted by Parashar and Venkatesh (2010), which showed that Islamic banks suffered much more than conventional banks in terms of capital ratio during the subprime crisis?

\subsection{Asset Quality}

According to Alhassan, Kyereboah-Coleman, and Andoh (20I4), the asset quality of bank loans corresponds to the degree to which borrowers respect their contractual commitments.

It is when a debtor does not repay his loan that he exposes the bank to credit risk, which is one of the main causes of bank failures. Exposure to this risk means that the credit institution has poor asset quality. (Hays, Lugio, Gilbert, 2008)

Similarly, Grier (2012) identifies poor asset quality as the main cause of bank failures. This can be explained by inappropriate lending policies.

However, evaluating asset quality is the most difficult aspect of banking analysis.

As a result, the better the asset quality, the more stable and resilient the bank is in the face of crises.

To assess this banking aspect, we consider the following ratio:

$$
\text { Asset Quality }=\frac{\text { TotalLoans }}{\text { TotalAssets }}(2)
$$

The higher this ratio, the more likely the bank is to face higher payment defaults.

Studies comparing the asset quality of Islamic and conventional banks show different results.

According to Beck et al. (2010), there is no difference in asset quality between the two types of banks. (Beck et al., 2010)

Also, Bourkhis and Nabi (2013) conclude that there are no significant differences in overall asset quality indicators before and after the financial crisis for Islamic and conventional banks.

However, Wahid and Dar (2016) find that the asset quality of conventional banks is better than the asset quality of 
Islamicbanks.

Similarly, according to Čihák and Hesse (2008) Islamic banks, especially large ones, have a higher loan to asset ratio than large commercial banks, and therefore lower assetquality.

Contrary to Shahid (2012) and Pappas, Ongena, Izzeldin, and Fuertes (2017) who conclude that the loan to asset ratio is lower for Islamic banks, and thus they reflect better asset quality.

\subsection{Management Efficiency}

This indicator of the CAMELS analysis makes it possible to identify the inadequacies of risk management policies and credit policies.

Given its qualitative aspect, it is difficult to assess it.

However, some indicators measure the quality of management through the way cost control is managed (Grier, 20I2).

To evaluate it, we use the cost-income ratio:

$$
\text { Cost to income }=\frac{\text { Operating Expenses }}{\text { Operating Income }}(3)
$$

Banks with a lower cost to income ratio indicate better efficiency (Wahid \& Dar, 2016).

Comparative studies of management efficiency between Islamic and conventional banks have shown several different results.

For Parashar and Venkatesh (2010) and Mohamad, Hassan and Bader (2008), no significant differences in efficiency before and during the crisis can be reported.

According to Bourkhis and Nabi (2013), there is no significant difference between Islamic banks and conventional banks before and during the financial crisis. But Islamic banks became more efficient only in 2009.

However, it is different for Shahid (2012), according to him Islamic banks are less efficient than conventional banks, which confirmed that conventional banks earned more income and spent less.

Similarly, for Ouerghi (20I4), the cost-to-income ratio of Islamic banks is higher than the ratio of conventional banks and therefore they present more managerial efficiency before and after the crisis. (Wahid \& Dar, 2016; Pappas et al., 2017; Alqahtani \& Mayes, 2018)

Very few studies have contradicted these results, notably that of Samad (1999) and Al-Jarrah and Molyneux (2005) who concluded that Islamic banks are more efficient.

\subsection{Earnings}

The importance of profits lies in their ability to deal with the potential risks that threaten banking institutions. Indeed, banks with high profits guarantee their competitive positions (Aguenaou, Lahrech, \& Bounakaya, 2017).

Thus, the ability of a bank to make a profit is essential for financial stability.

In other words, strong bank profits are the engine of the operational and sustainable functioning of the bank (Grier, 2012). We measure bank profitability by two separate ratios, namely the return on equity (ROE) ratio and the return on assets ( $\mathrm{ROA})$ ratio. The higher these ratios, the more profitable the bank is:

$$
\begin{gathered}
\text { ROE }=\frac{\text { Net Income }}{\text { Total Equity }}(4) \\
\text { ROA }=\frac{\text { Net Income }}{\text { Total Assets }}
\end{gathered}
$$

Studies comparing the profitability of conventional and Islamic banks have shown different results.

Parashar and Venkatesh (2010) find that Islamic banks have a better profitability than conventional banks, specifically the ROA ratio which was higher for Islamic banks before and during the crisis. While no difference was recorded in terms of ROE during the crisis between the two types of banks, however, Islamic banks had a higher ROE before the crisis.

Similarly, Bourkhis and Nabi (2013) conclude that no significant difference was reported between the profitability of Islamic and conventional banks for the period 1998 to 2006. However, the profitability of Islamic banks improved during and after the crisis.

In the same line, Youssef (2017) demonstrated that Islamic banks responded better in terms of profitability than their conventional counterparts during the financial crisis (Pappas et al., 2017; Bourkhis \& Nabi, 20I3).

Unlike Ouerghi (2014) who finds a different result. According to the author, conventional banks are more profitable than Islamic banks especially in times of crisis. The profitability of Islamic banks is higher only after the crisis. 
According to Wahid and Dar (2016), Alqahtani and Mayes (2018) conventional banks have a higher ROA than Islamic banks.

\subsection{Liquidity}

Liquidity has a revealing impact on financial stability, as poor liquidity management is capable of producing the failure of banking institutions (Hilbers, Krueger, \& Moretti, 2000).

We measure bank liquidity by the following ratio:

$$
\text { Liquidity }=\frac{\text { Liquid Assets }}{\text { Total Assets }}(5)
$$

Indeed, the interpretation of liquidity ratios is difficult. This is because a high liquidity ratio may reflect the high level of confidence that depositors have in their depositors and therefore that their bank is financially stable. As it can mean that the bank suffers from a weak investment cycle and therefore it can be linked to a high level of banking instability (Gunsel, 2007). Regarding comparative studies between the liquidity of conventional and Islamic banks, Parashar and Venkatesh (20I0) show that conventional banks suffered more than Islamic banks in terms of liquidity during the crisis. Pappas et al. (2017) demonstrate also that Islamic banks are more liquid than conventional banks.

This result is the opposite of what Alqahtani and Mayes (2018) demonstrated, they assume that Islamic banks are less liquid than conventional banks.

However, Bourkhis and Nabi (2013) find no significant difference between Islamic and conventional banks in terms of liquidity before, during and after the crisis.

\section{Empirical Study}

\section{I Methodology and Sample}

To measure the stability of Islamic and conventional banks, we adopt the CAMEL method.

To do so, we have calculated financial ratios from the annual reports of 6 Islamic banks and 6 conventional banks for the period from 2005 to 2014 to examine the effect of the subprime crisis on these ratios; therefore we will have the following periods;

$$
\begin{array}{ll}
\text { - } & \text { Pre-Crisis2005-2006 } \\
\text { - } \quad \text { Crisis2007-2008 } \\
\text { - } \quad \text { Post-Crisis2009-20I4 }
\end{array}
$$

Table I. List of conventional banks

\begin{tabular}{ll}
\hline Conventional Banks & Countries \\
\hline Ahli Bank QSC & Qatar \\
\hline Arab Banking Corporation & Bahrain \\
\hline Burgan Bank & Kuwait \\
\hline Emirates Investment Bank & United ArabEmirates \\
\hline Future Bank & Bahrain \\
\hline Gulf International Bank & Bahrain \\
\hline
\end{tabular}

Table 2. List of Islamic banks

\begin{tabular}{ll}
\hline Islamic Banks & Countries \\
\hline Bahrain Islamic Bank B.S.C. & Bahrain \\
\hline Bank Boubyan & Kuwait \\
\hline Emirates Islamic Bank & United ArabEmirates \\
\hline Khaleeji Commercial Bank & Bahrain \\
\hline Kuwait Finance House & Kuwait \\
\hline Qatar Islamic Bank & Qatar \\
\hline
\end{tabular}

\section{Findings and Discussion}

The results of the financial ratios are as follows:

\section{I Capital Adequacy}

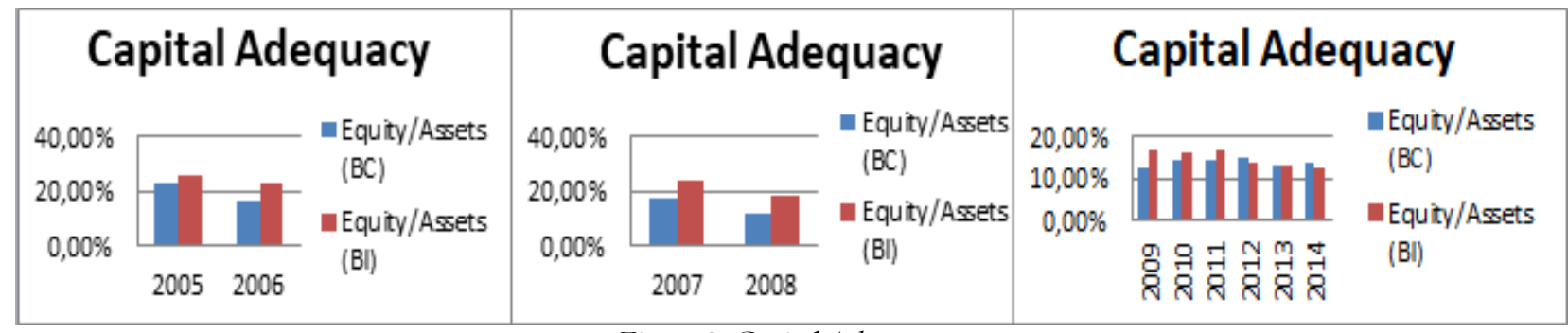

Figure 2. Capital Adequacy 
We note that before the crisis, Islamic banks had a higher level of capitalization than that of conventional banks during 2005-2006, with an average of $26.2 \%$ in 2005 for Islamic banks and $23.3 \%$ for conventional banks, i.e. a difference of $2.8 \%$. This variation is kept on the rise, reaching a $6.3 \%$ difference in 2006 in favor of Islamic banks. This situation is maintained even during the crisis, in 2007 the average Equity to Total Assets ratio for Islamic banks is $23.79 \%$, while for conventional banks it is $17.35 \%$, another difference of $6.44 \%$ in 2007 .

The difference between the capitalizations of the two types of banks is $6.12 \%$ in 2008 . These results are in line with those of Wahid and Dar (2016).

It is since 2012 that capitalization of conventional banks improved with a slight difference compared to their conventional counterparts, to around $1 \%$.

This increase is explained in large part by the introduction of Basel III regulations in 20I0, which aimed to strengthen the quality and quantity of equity.

\subsection{Asset Quality}

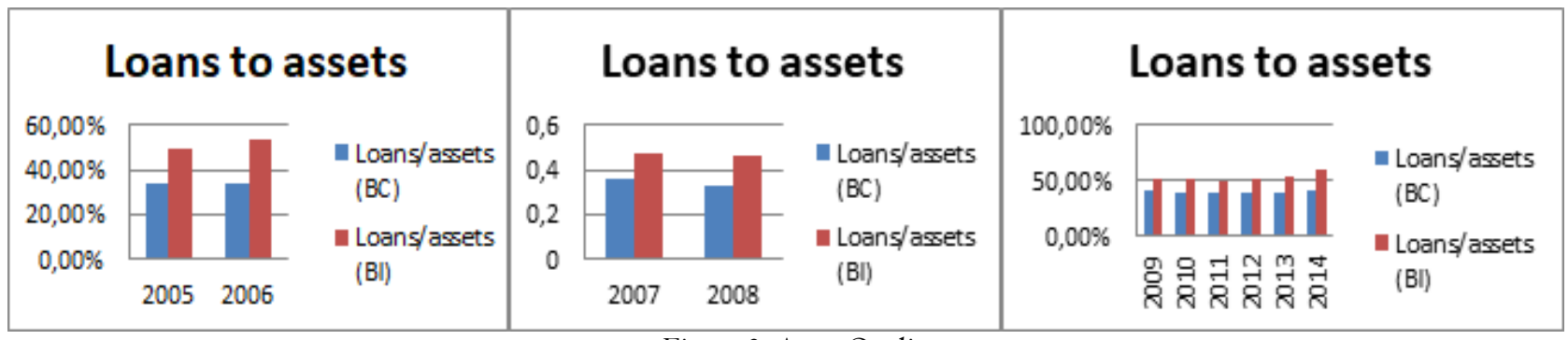

Figure 3. Asset Quality

Before during, and after the crisis, we notice that Islamic banks have a higher loan to asset ratios than conventional banks. That is, they have poor asset quality compared to conventional banks and as a result, they face more defaults.

This result is in line with the work of Wahid and Dar (2016) and Čihák and Hesse (2008), who concluded that the quality of assets of conventional banks is better than that of Islamic banks.

\subsection{Management Efficiency}

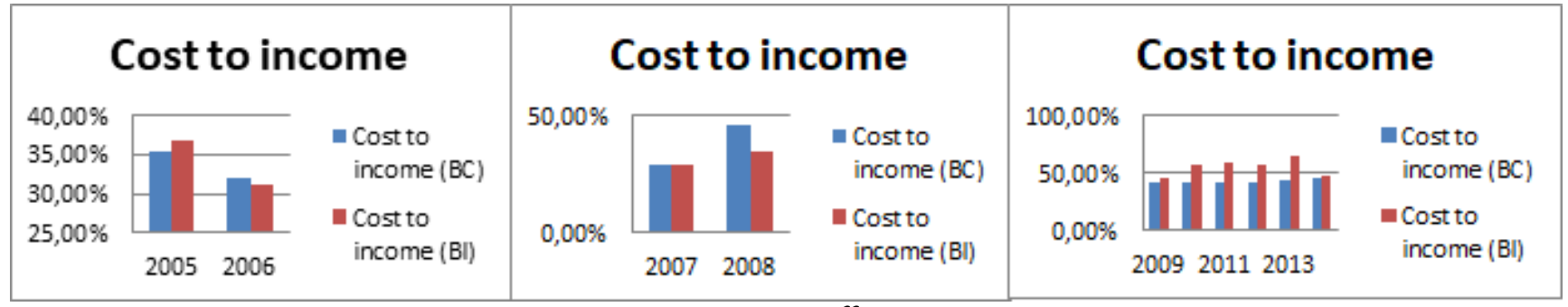

Figure 4. Management Efficiency

Concerning the cost to income ratio, there is one important difference to report. Indeed, in 2005, Islamic banks had a slightly higher cost to income ratio than conventional banks with a difference of $1 \%$. This same ratio decreased in 2006 for Islamic banks, with a difference of $\mathrm{I} \%$ with conventional banks.

We can conclude that no significant difference is to be reported before the crisis. It is only in 2008 that it records a significant variation estimated at I I.45\% in favor of conventional banks, which are considered inefficient in cost management. However, the post-crisis period was characterized by a higher cost-income ratio of Islamic banks than conventional banks, and thus by the cost inefficiency of Islamic banks.

These findings confirm the results of Ouerghi (20I4).

We explain the efficiency of conventional banks after the crisis by their ability to generate income through different sources, loans, productive assets, or even non-interest income.

The managerial inefficiency of Islamic banks after the crisis is explained by the expansion of the Islamic banking industry as an alternative to conventional banks, which has led to a growing demand for Islamic products, which are characterized by their complexities and therefore by high costs. 


\subsection{Earnings}

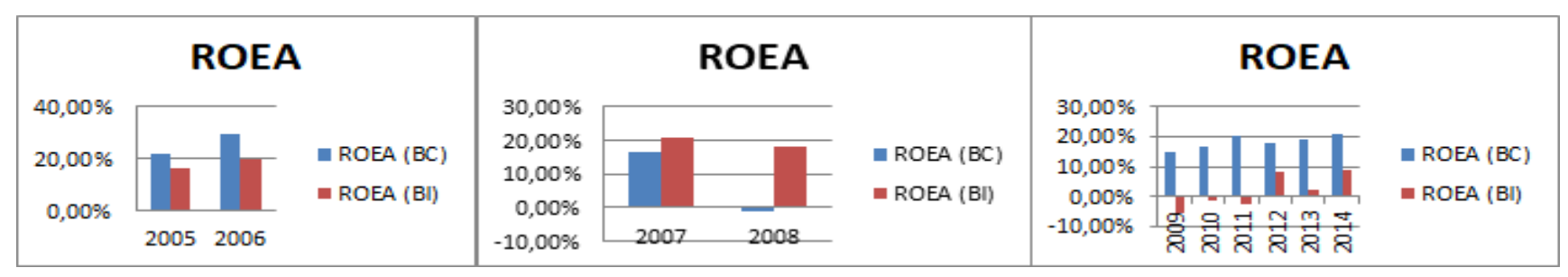

Figure 5. Return on Assets

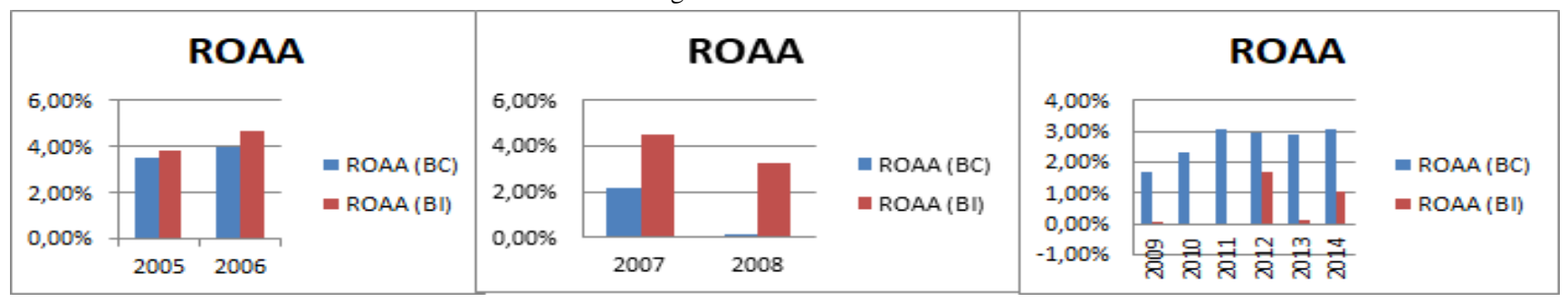

Figure 6. Return on Equity

Before the crisis, the profitability (ROE) of conventional banks exceeded the profitability of Islamic banks by about $5 \%$ in 2005 and by $9 \%$ in 2006.

In terms of ROA, Islamic banks exceeded conventional banks in 2005 by $0.32 \%$ and in 2006 by $0.72 \%$.

However, in times of crisis, the ROA and ROE of Islamic banks were higher than the ratios of conventional banks with an important difference.

After the crisis, the ROA and ROE of conventional banks largely exceeded those of Islamic banks.

We conclude that Islamic banks have suffered less in terms of profitability than conventional banks. These results agree with the study of Youssef (2017).

These results are explained by the high net income margin at the level of Islamic banks from financing activities resulting from investment deposits as a cheaper source of funding compared to the equity money market, and interbank activities of conventional banks.

\subsection{Liquidity}

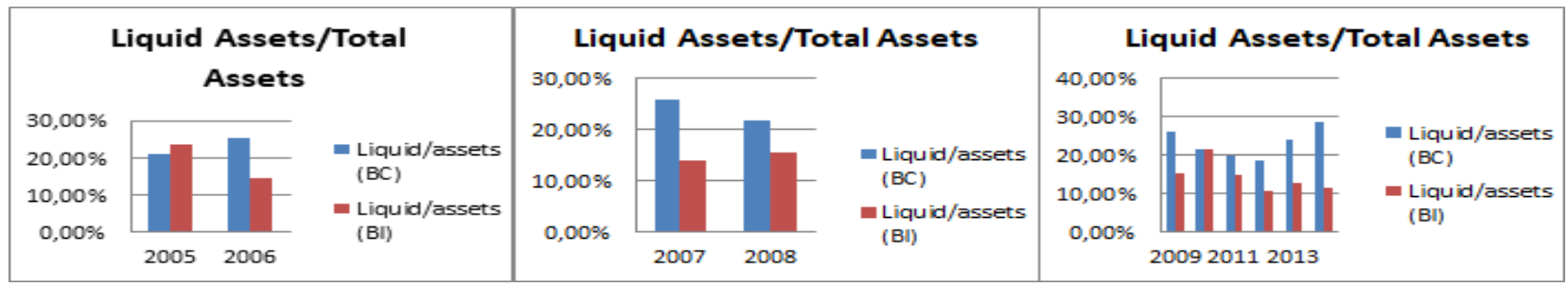

Figure 7. Liquidity

Before the crisis, and precisely in 2005, Islamic banks were more liquid than conventional banks, with a difference of $2.77 \%$. As of 2006, the liquidity of conventional banks increased exceeding the liquidity of Islamic banks by I0.73\%. This situation is maintained during and after the crisis. These results are in line with the results of Alqahtani and Mayes (2018).

Indeed, Islamic banks are not allowed to use hedging instruments, which explains their low liquidity. Moreover, the non-existence of a money market adequate to the operations of Islamic banks largely explains their liquidity problems.

Through the results of the CAMELS method, we can conclude that during the subprime crisis, Islamic banks reacted better than conventional banks, in terms of capital adequacy, earnings, and management efficiency. However, conventional banks suffered less in terms of liquidity and asset quality. These results indicate that Islamic banks are much more resilient than conventional banks in times of crisis. 


\section{Conclusion}

The recent global financial crisis had induced a series of failures of many conventional banks and led many economists to advocate for favoring the development of Islamic banks in the MENA region arguing their higher soundness during the financial crises. This paper attempted to answer empirically the following question: What was the effect of the 2007-2008 financial crises on the soundness of the Islamic banks and their conventional peers?

To answer this question we considered a matched sample comprising 6 Islamic banks and 6 conventional banks from the MENA region and applied the CAMELS framework based on a set of financial soundness indicators (FSIs) related to the banks' earnings and profitability, capitalization, asset quality, efficiency and liquidity.

The results showed that there is a significant difference between Islamic banks and conventional banks. We found that Islamic banks outperformed conventional banks concerning capitalization efficiency, and profitability during the financial crisis. However, conventional banks outperformed Islamic banks concerning liquidity and asset quality. We can conclude that Islamic banks were more resilient than conventional banks in a period of crisis. However, these results remain to be confirmed by a more precise econometric study taking into account several aspects such as the size age of banks, and macroeconomic indicators.

\section{References}

Aguenaou, S., Lahrech, A., \& Bounakaya, S. (2017). Analyzing Banks' Efficiency as a Measurement of Performance in the Moroccan Context: Application of CAMEL Framework. International Review of Research in Emerging Markets and the Global Economy (IRREM), 3(I),II05-II2I.

Alhassan, A. L., Kyereboah-Coleman, A., \& Andoh, C. (2014). Asset quality in a crisis period: An empirical examination of Ghanaian banks. Review of Development Finance, 4(I),50-62.

Al-Jarrah, I., \& Molyneux, P. (2005). Efficiency in Arabian banking. In M. Iqbal, \& R. Wilson (Eds.), Islamic Perspectives on Wealth Creation (pp. 25-43). Edinburgh University Press: Edinburgh.

Alqahtani, F., \& Mayes, D. G. (2018). Financial stability of Islamic banking and the global financial crisis: Evidence from the Gulf Cooperation Council. Economic Systems, 42(2), 346-360.

Askari, H., \& Krichene, N. (2014). Islamic Finance: An Alternative Financial System for Stability, Equity, and Growth. PSL Quarterly Review,67(268), 9-54.

Balteş, N., Rodean, C., \& Daciana, M. (20I4). Study regarding the Financial stability of commercial banks listed on Bucharest Stock Exchange of CAMELS rating outlook. Journal of International Studies, 7(3), I33-I43.

Bank Negara Malaysia. (n.d.). The Importance of Financial Stability. Retrieved from: https://www.bnm.gov.my/index.php?ch=fs\&pg=fs_ovr_imp\&ac=I I4

Bank of Korea. (n.d.). Why is Financial Stability Important? Retrieved from: https://www.bok.or.kr/eng/main/contents.do?menuNo=400037

Beck, T., Demirgüç-Kunt, A., \& Merrouche, O. (2010). Islamic vs. Conventional Banking: Business Model, Efficiency and Stability. Policy Research Working Paper 5446.

Bourkhis, K., \& Nabi, M. S. (2013). Islamic and conventional banks' soundness during the 2007-2008 financial crisis. Review of Financial Economics, 22(2), 68-77.

Chant, J., Lai, A., Illing, M., \& Fred, D. (2003). Essays on Financial Stability. Technical Report No95. Bank of Canada, I-I I I. Chapra, M. U. (2009). Ethics and Economics: An Islamic Perspective. Islamic Economic Studies, I6(I\&2).

Chishti, S. U. (1985). Relative Stability of Interest-free Economy الاستقرار النسبي في اقتصاد لاربوي. Journal of Research in Islamic Economics, King Abdulaziz University. Islamic Economics Institute, 3(I), 3-I2.

Čihák, M., \& Hesse, H. (2008). Islamic Banks and Financial Stability: An Empirical Analysis.IMF Working Paper WP/O8. International Monetary Fund. Monetary and Capital Markets Department. Washington, I-29.

Crockett, A. (1997). Why Is Financial Stability a Goal of Public Policy ?. Economic Review. Federal Reserve Bank Of Kansas City, 82(4), 5-22.

de la Banque, S. F. D. Centrale des Etats de llAfrique de llOuest (BCEAO), Dispositif Institutionnel (2006).

Faouzi, A., \& Houhou, S. (2008). Un modele d'alerte precoce de difficultes bancaires pour les pays émergents. Economie Internationale, II4, 69-92.

Ferguson, R.W. (2002). Should Financial Stability Be An Explicit Central Bank Objective?. Paper presented at the Conference at the IMF in Washington, D.C.

Fisher, I. (1936). I00\% Money and The Public Debt. New York: Adelphi Company

Foot, M. (2003). What is Financial Stability and How Do We Get It?.The Roy Bridge Memorial Lecture. Financial Services Authority. April.

Grier, W. A. (2012). Credit Analysis of FinancialInstitutions (3rd ed.). Euromoney Institutional Investor PLC: Playhouse Yard Gunsel, N. (2007). Financial Ratios and the Probabilistic Prediction of Bank Failure in North Cyprus. European Journal of Scientific Research, I8(2), I9I-200. 
Hays, F., Lurgio, S., \& Gilbert, A. (2008). Efficiency Ratios and Community Bank Performance. Journal of Finance and Accountancy, 5(2), I-I5.

Hilbers, P., Krueger, R., \& Moretti, M. (2000). De nouveaux outils pour évaluer la santé du système financier. Finances \& Développement, $\quad 53-55 . \quad$ Retrieved from https://www.imf.org/external/pubs/ft/fandd/fre/2000/09/pdf/hilbers.pdf

International Monetary Fund. (2006). Financial Soundness Indicators : Compilation Guide. Publication Services. Washington.

Mansour, N., \& Zouari, E. (2018). Banking Interaction And Financial Stability: MENA Countries. Global Joumal of Management and Business Research: C Finance, I8 (8), I I-24.

Minsky, H. (1986). Stabilizing an Unstable Economy: A Twentieth Century Fund Report (Ist ed.). New Haven and London: Yale University Press.

Mishkin, F. S. (1997). The Causes and Propagation of Financial Instability: Lessons for Policymakers. Proceedings- Economic Policy Symposium- Jackson Hole. Federal Reserve Bank Of Kansas City. 55-96.

Mohamad, S., Hassan, T., \& Bader, M. K. I. (2008). Efficiency of conventional versus Islamic banks: international evidence usingthe stochastic frontier approach (SFA). Journal of Islamic Economics, Banking and Finance, 4,I07-I30.

Ouerghi, F. (20I4). Are Islamic Banks More Resilient To Global Financial Crisis Than Conventional Banks ?. Asian Economic and Financial Review, 4(7), 94I-955.

Padoa-Schioppa, T. (2003). Central Banks And Financial Stability: Exploring a Land in Between, The Transformation of The European Financial System. Paper presented at the Central Banking Conference. Frankfurt. Retrieved from https://www.ecb.europa.eu/events/pdf/conferences/tps.pdf

Pappas, V., Ongena, S., Izzeldin, M., \& Fuertes, A. (2017). A Survival Analysis of Islamic and Conventional Banks. Journal of Financial Services Research, 5I(2), 22I-256.

Parashar, S. P., \& Venkatesh, J. (2010). How did Islamic banks do during global financial crisis?. Banks and Bank Systems, $5(4), 54-62$.

Patat, J. P. (2000). La stabilité financière, nouvelle urgence pour les banques centrales. Bulletin de la Banque de France $n^{\circ} 84$. Décembre, 49-6I.

Sakti, M. R. P., \& Mohamad, A. (2018). Efficiency, stability and asset quality of Islamic vis-à-vis conventional banks. Journal of Islamic Accounting and Business Research, 9(3), 378-400.

Roman, A., \& Şargu, A. (2013). Analysing the Financial Soundness of the Commercial Banks in Romania: An Approach Based on the Camels Framework. Procedia Economics and Finance, 6, 703-712.

Salman, S. A. (2007). Financial Distress And Bank Failure: Lessons From Closure Of Ihlas Finans In Turkey. Islamic Economic Studies. The Islamic Research and Training Institute (IRTI), I4 (I\&2), 2-52.

Samad, A. (I999). Comparative efficiency of the Islamic bank vis-a'-vis conventional banks in Malaysia, IIUM Journal of Economics and Management, 7, I-25.

Santomero, A. M., \& Watson, R. D. (1977). Determining an Optimal Capital Standard for the Banking Industry. The Journal of Finance, 32(4), 1267-I282.

Schinasi, G. J. (2004). Defining Financial Stability.IMF Working Papers 04/I87. International Monetary Fund.

Shahid, M. A. (2012). Financial stability of Islamic banking in Pakistan: An empirical study. African Journal of Business Management, 6(IO), 3706-37I4.

Simons, H. C. (1948). Economic Policy for a Free Society .Chicago (IL): University of Chicago Press.

Srairi, S. A. (2010). Cost and profit efficiency of conventional and Islamic banks in GCC countries. Journal of Productivity Analysis, 34(I), 45-62.

Tayyebi, A. (2009). Eclipse by the Crescent Moon: Islamic Finance provides some light in the Global Financial Crisis. Financial Services Review, ACCA Global, June.

Uyen, D. (20II). The CAMEL rating system in banking supervision. A case study (Thesis, Arcada University of Applied Sciences International Business). Retrieved from https://www.theseus.fi/bitstream/handle/I0024/38344/Dang_Uyen.pdf

Wahid, M. A., \& Dar, H. (2016). Stability of Islamic versus Conventional Banks: A Malaysian Case. Jurnal Ekonomi Malaysia, $50(I)$, I I I $-\mathrm{I} 32$

Youssef, M. H. (2017). Financial stability of Islamic and conventional banks (Master Thesis). Retrieved from http://lup.lub.lu.se/student-papers/record/8912576

Zainol, Z., \& Kassim, S. H. (2012). A critical review of the literature on the rate of return risk in Islamic banks. Journal of Islamic Accounting and Business Research, 3(2), I2 I-I37. 
Appendices

Appendix A: Table 3. Conventional bank ratios

\begin{tabular}{|c|c|c|c|c|c|c|}
\hline Years & ROAA & Equity/Assets & $\begin{array}{l}\text { Cost to } \\
\text { Income }\end{array}$ & ROEA & Liquid/assets & Loans/assets \\
\hline 2005 & $3,48 \%$ & $23,34 \%$ & $35,34 \%$ & $21,72 \%$ & $20,99 \%$ & $33,74 \%$ \\
\hline 2007 & $2,12 \%$ & $17,35 \%$ & $29,50 \%$ & $16,5 \mathrm{I} \%$ & $25,76 \%$ & $35,91 \%$ \\
\hline 2008 & $0,16 \%$ & II,86\% & $45,80 \%$ & -I,I I\% & $21,99 \%$ & $32,77 \%$ \\
\hline 2009 & $\mathrm{I}, 69 \%$ & $\mathrm{I} 2,44 \%$ & $41,46 \%$ & $15,03 \%$ & $26,05 \%$ & $40,53 \%$ \\
\hline 2011 & $3,04 \%$ & $14,36 \%$ & $42,74 \%$ & $20,02 \%$ & $19,80 \%$ & $38,94 \%$ \\
\hline 2012 & $2,93 \%$ & $15,23 \%$ & $42,09 \%$ & $18,01 \%$ & $18,60 \%$ & $39,79 \%$ \\
\hline 2013 & $2,90 \%$ & $13,39 \%$ & $44,04 \%$ & $19,14 \%$ & $23,90 \%$ & $39,27 \%$ \\
\hline 2014 & $3,07 \%$ & $13,96 \%$ & $46,16 \%$ & $20,75 \%$ & $28,79 \%$ & $42,45 \%$ \\
\hline
\end{tabular}

Appendix B. Table 4 . Islamic bank ratios

\begin{tabular}{|c|c|c|c|c|c|c|}
\hline Years & ROAA & Equity/Assets & $\begin{array}{l}\text { Cost } \\
\text { income }\end{array}$ & ROEA & Liquid/assets & Loans/assets \\
\hline 2005 & $3,80 \%$ & $26,17 \%$ & $36,69 \%$ & $16,06 \%$ & $23,76 \%$ & $49,09 \%$ \\
\hline 2006 & $4,66 \%$ & $22,73 \%$ & $3 \mathrm{I}, 08 \%$ & $20,18 \%$ & $\mathrm{I} 4,50 \%$ & $53,48 \%$ \\
\hline 2007 & $4,5 \mathrm{I} \%$ & $23,79 \%$ & $28,69 \%$ & $20,59 \%$ & $14,11 \%$ & $47,33 \%$ \\
\hline 2008 & $3,24 \%$ & $17,97 \%$ & $34,35 \%$ & $18,06 \%$ & $15,60 \%$ & $46,60 \%$ \\
\hline 2009 & $0,07 \%$ & $16,59 \%$ & $44,77 \%$ & $-5,45 \%$ & $\mathrm{I} 5,4 \mathrm{I} \%$ & $52,80 \%$ \\
\hline 2010 & $-0,01 \%$ & $16,07 \%$ & $57,15 \%$ & $-1,55 \%$ & $21,61 \%$ & $52,58 \%$ \\
\hline $201 \mathrm{I}$ & $-0,02 \%$ & $16,63 \%$ & $58,41 \%$ & $-2,55 \%$ & $14,72 \%$ & $50,23 \%$ \\
\hline 2012 & $\mathrm{I}, 67 \%$ & $\mathrm{I} 3,87 \%$ & $57,40 \%$ & $8,39 \%$ & $\mathrm{I} 0,58 \%$ & $52,02 \%$ \\
\hline 2013 & $0, \mathrm{I} 2 \%$ & $13,37 \%$ & $65,00 \%$ & $2,50 \%$ & $12,98 \%$ & $54,37 \%$ \\
\hline 2014 & $\mathrm{I}, 03 \%$ & $\mathrm{I} 2,54 \%$ & $47,99 \%$ & $8,87 \%$ & II, $53 \%$ & $59,18 \%$ \\
\hline
\end{tabular}

\section{Copyrights}

Copyright for this article is retained by the author(s), with first publication rights granted to the journal. This is an open-access article distributed under the terms and conditions of the Creative Commons Attribution license (http://creativecommons.org/licenses/by/4.0/). 